PACS numbers: 87.23._n, 89.60._k, 07.88._y

\title{
WAVELET AND MULTIFRACTAL ANALYSIS OF THE NONLINEAR STRUCTURES IN CHAOTIC PROCESSES FOR HYDROECOLOGICAL SYSTEMS
}

\author{
N.G. Serbov, Cand.Sci, (Geogr.), \\ O.Yu. Khetselius, Dr. Sci. (Phys.-Math.) \\ A.A. Svinarenko, Dr. Sci. (Phys.-Math.), \\ O.N. Grushevsky, Cand.Sci. (Geogr.) \\ Odessa State Environmental University, 15 , \\ Lvivska St., 65016 Odessa, Ukraine, svinarenkoaa@gmail.com
}

\begin{abstract}
This paper goes on our investigations of the fractal structures in the chaotic and turbulent processes and connected with a great importance the experimental and theoretical studying of the non-linear dynamical systems with aim to discover the fractal features and elements of dynamical chaos. In this paper on the basis of wavelet analysis and multifractal formalism it is carried out an analysis of fractal structures in the chaotic processes (the time series of the nitrates concentrations in the Small Carpathians river's watersheds SvidnikOndrava in the Earthen Slovakia) and the spectrum of the fractal dimensions has been computed. It is carried out numerical modelling and fulfilled a comparison of theoretical data with the earlier received estimates on the basis of other fractal formalism algorithm.
\end{abstract}

Key words: hydrological systems, fractals structures, chaotic processes, the time series of pollutants concentrations

\section{INTRODUCTION}

This paper goes on our investigations of the fractal structures in the chaotic and turbulent processes [1,2]. Let us remind that in last years it is of a great importance the experimental and theoretical studying of the non-linear dynamical systems with aim to discover the fractal features and elements of dynamical chaos (e.g. [3-23]). One of the effective approaches to solving such a problem is the multifractal and wavelet analyses. The foundations and application information on the continuous wavelet transform-based method of multifractal analysis are presented in Ref. [3]. An extension of the concept of multifractals to irregular functions through the use of wavelet transform modulus maxima and potential and limitations of the multifractal formalism in the study of nonstationary processes and short signals are in details considered in these references. Especial attention is turned to the multifractality loss effects in the dynamics of different types of systems. A review of fundamental results on the manifestation of fractal structure in wave (turbulent) processes is presented in [3].

As it is indicated in many references (e.g. [3]) the most natural and effective illustration of the chaos effect can be observed in turbulent flows. In papers by Zaslavsky et al (e.g. [5]) the fractal properties of the sea surface have been considered on the scales which are more than the distortion correlation radius.

In this paper on the basis of wavelet analysis and multifractal formalism it is carried out an analysis of fractal structures in the chaotic processes (the time series of the nitrates concentrations in the Small Carpathians river's watersheds Svidnik-Ondrava in the Earthen Slovakia) and the spectrum of the fractal dimensions has been computed. It is carried out numerical modelling and fulfilled a comparison of theoretical data with the earlier received estimates on the basis of other fractal formalism algorithm.

\section{METHOD: WAVELET EXPANSIONS AND MULTI- FRACTALS}

As the key elements of the wavelet-analysis and multifractal formalism have been presented earlier in details (see for example, $[1,2]$ ), here we are limited only by the key aspects. According to $[1,2]$, the theoretical tool is in fact based on the wavelet decomposition for analyzing various signals. At present, the family of analyzing function dubbed wavelets are being increasingly used in problems of pattern recognition; in processing and synthesizing various signals; in analysis of images of any kind (Xray picture of a kidney, an image of mineral, etc.); for study of turbulent fields, for contraction (compression) of large volumes of information, and in many other cases.

Wavelets are fundamental building block functions, analogous to the sine and cosine functions. Fourier transform extracts details from the signal frequency, but all information about the location of a particular frequency within the signal is lost. At the expense of their locality the wavelets have advantages over Fourier transform 
when non-stationary signals are analyzed. Here, we use non-decimated wavelet transform that has temporal resolution at coarser scales [1,2].

The dilation and translation of the mother wavelet $\psi(t)$ generates the wavelet as follows: $\psi j, k(t)=2 j / 2 \psi(2 j t$ $-k)$. The dilation parameter $j$ controls how large the wavelet is, and the translation parameter $k$ controls how the wavelet is shifted along the t-axis. For a suitably chosen mother wavelet $\psi(t)$, the set $\{\psi j, k\} j, k$ provides an orthogonal basis, and the function $f$ which is defined on the whole real line can be expanded as

$$
f(t)=\sum_{k=-\infty}^{\infty} c_{0 k} \varphi_{0, k}(t)+\sum_{j=1}^{J} \sum_{k=-\infty}^{\infty} d_{j k} \psi_{j, k}(t)
$$

where the maximum scale $J$ is determined by the number of data, the coefficients $c_{0 k}$ represent the lowest frequency smooth components, and the coefficients $d_{j k}$ deliver information about the behavior of the function $f$ concentrating on effects of scale around $2-j$ near time $k \times$ $2-j$. This wavelet expansion of a function is closely related to the discrete wavelet transform (DWT) of a signal observed at discrete points in time. In practice, the length of the signal, say $n$, is finite and, for our study, the data are available monthly, i.e. the function $f(t)$ in Eq. (1) is now a vector $\mathbf{f}=\left(f\left(t_{1}\right), \ldots, f\left(t_{n}\right)\right)$ with $t_{i}=i / n$ and $i=1, \ldots$, $n$. With these notations, the DWT of a vector $\mathbf{f}$ is simply a matrix product $d=W f$, where $d$ is an $\mathrm{n} \times 1$ vector of discrete wavelet coefficients indexed by 2 integers, $d_{j k}$, and $W$ is an orthogonal $n \times n$ matrix associated with the wavelet basis. For computational reasons, it is simpler to perform the wavelet transform on time series of dyadic (power of 2) length. One particular problem with DWT is that, unlike the discrete Fourier transform, it is not translation invariant. This can lead to Gibbs-type phenomena and other artefacts in the reconstruction of a function. The non-decimated wavelet transform (NWT) of the data $\left(f\left(t_{1}\right), \ldots, f\left(t_{n}\right)\right)$ at equally spaced points $t_{i}=i / n$ is defined as the set of all DWT's formed from the $\mathrm{n}$ possible shifts of the data by amounts $i / n ; i=1, \ldots, n$.

Thus, unlike the DWT, there are $2^{j}$ coefficients on the $j^{\text {th }}$ resolution level, there are $\mathrm{n}$ equally spaced wavelet coefficients in the NWT

$$
\begin{aligned}
& d_{j k}=n^{-1} \sum_{i=1}^{n} 2^{j / 2} \psi\left[2^{j}(i / n-k / n)\right] y_{i}, \\
& k=0, \ldots, n-1,
\end{aligned}
$$

on each resolution level $j$. This results in $\log 2(\mathrm{n})$ coefficients at each location. As an immediate consequence, the NWT becomes translation invariant. Due to its structure, the NWT implies a finer sampling rate at all levels and thus provides a better exploratory tool for analyzing changes in the scale (frequency) behavior of the underly- ing signal in time. These advantages of the NWT over the DWT in time series analysis are demonstrated in Nason et al (e.g.[12]). As in the Fourier domain, it is important to assess the power of a signal at a given resolution. An evolutionary wavelet spectrum (EWS) quantifies the contribution to process variance at the scale $\mathrm{j}$ and time $\mathrm{k}$. Another way of viewing the result of a NWT is to represent the temporal evolution of the data at a given scale. This type of representation is very useful to compare the temporal variation between different time series at given scale. To obtain the results, smooth signal S0 and the detail signals $D_{j}(j=1, \ldots, J)$ are:

$$
S_{0}(t)=\sum_{k=-\infty}^{\infty} c_{0 k} \varphi_{0, k}(t)
$$

and

$$
D_{j}(t)=\sum_{k=-\infty}^{\infty} d_{j k} \psi_{j, k}(t)
$$

The fine scale features (high frequency oscillations) are captured mainly by the fine scale detail components $D_{J}$ and $D_{J}-1$. The coarse scale components $S_{0}, D_{1}$, and $D_{2}$ correspond to lower frequency oscillations of the signal. Note that each band is equivalent to a band-pass filter. Further we use the Daubechies wavelet as mother wavelet [11]. This wavelet is bi-orthogonal and supports discrete wavelet transform. Using a link between wavelets and fractals, one could make calculating the multi-fractal spectrum. As usually, the homogeneous fractals are described by single fractal dimension $D(0)$. Nonhomogeneous or multifractal objects are described by spectrum $\mathrm{D}(\mathrm{q})$ of fractal dimensions or multifractal spectrum A problem of its calculation reduces to definition of singular spectrum $f(\alpha)$ of measure $\mu$. It associates Haussdorff dimension and singular indicator $\alpha$, that allows calculating a degree of singularity: $N \alpha(\varepsilon)=\varepsilon-f(\alpha)$. Below we use a formalism, which allows defining spectra of singularity and fractal dimension without using standard Legandre transformations. Wavelet transformation of some real function $\mathrm{F}$ can be also defined as [1]

$$
\mathrm{W}_{\Psi}[F](b, a)=(1 / \alpha) \int_{-\infty}^{+\infty} F(x) \Psi\left(\frac{x-b}{a}\right) d x
$$

where parameter $b$ denotes a shift in space (a space scale). The analyzing splash $\Psi$ has to be localized as in space as on frequency characteristics. The most correct way of estimate of the function $D(h), f(\alpha)$ is in analysis of changing a dependence of the distribution function $Z(q, a)$ on modules of maximums of the splash-transfers under scale changes

$$
Z=\sum_{i=1}^{N(a)}\left(\omega_{i}(a)\right)^{q}
$$




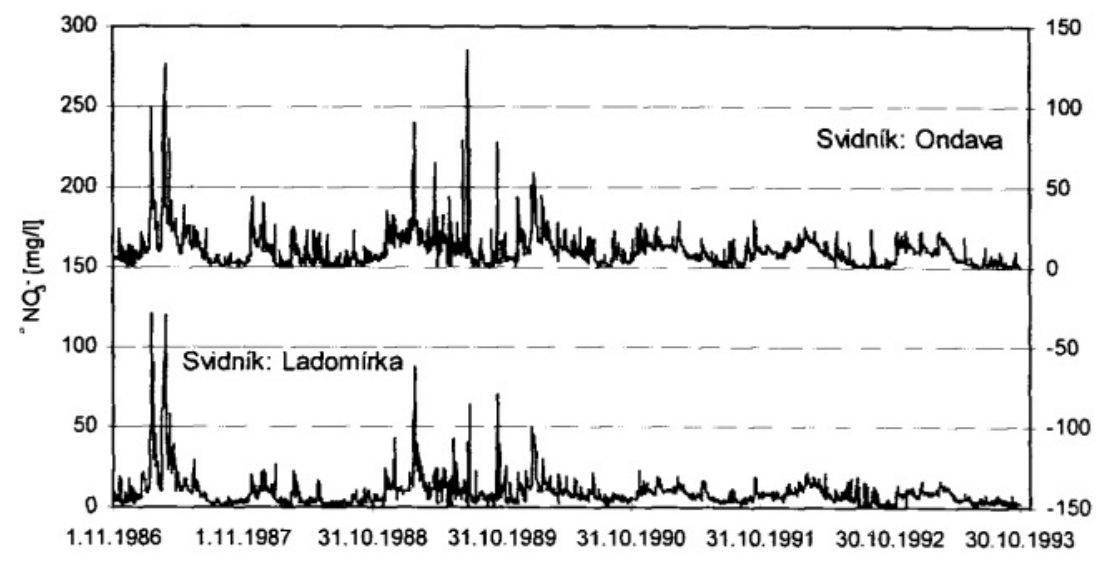

Fig. 1 - The temporal changes in the concentrations of nitrates in some catchment of the Small Carpathians (Slovakia) [12].

where $I=1, \ldots, N(\mathrm{a}) ; N(\mathrm{a})$ is a number of localized maximums of transformation $\mathrm{W} \Psi[\mathrm{F}](\mathrm{b}, \mathrm{a})$ for each scale $a$; function $\omega$ (a) can be defined in terms of coefficients of the splash-transformations as

$$
\begin{aligned}
& \omega_{i}(a)=\max \left|W_{\Psi}[F]\left(x, a^{\prime}\right)\right|, \\
& \left(x, a^{\prime}\right) \in L \\
& a^{\prime}<a
\end{aligned}
$$

where $\operatorname{li} \in L(\mathrm{a}) ; L(\mathrm{a})$ is a set of such lines, which make coupling the splash-transformation coefficient maximums (they reach or make cross-section of a level, which is corresponding to scale a). In the limit a $\rightarrow 0+$ the distribution function $Z(q, a)$ manifests the behaviour, which is corresponding to a degree law:

$$
Z(q, a) \sim a \tau(q) .
$$

To calculate a singularity spectrum, the standard canonical approach can be used. It is based on using such functions:

$$
\begin{gathered}
h(a, q)=\frac{1}{Z(a, q)} \frac{\partial Z(a, q)}{\partial q}, \\
\frac{\partial Z}{\partial q}=\sum_{i=l}^{N(a)} \omega_{i}(a)^{q} \ln \omega_{i}(a), \\
D(a, q)=q h(a, q)-\ln Z(a, q) .
\end{gathered}
$$

The spectra $D(q)$ and $h(q)$ are defined by standard way as follows:

$$
\begin{aligned}
& D(q)=\lim _{a \rightarrow 0} \frac{D(a, q)}{\ln a}, \\
& h(q)=\lim _{a \rightarrow 0} \frac{h(a, q)}{\ln a} .
\end{aligned}
$$

Other details can be found in Refs. [11,15-18].

\section{RESULTS AND CONCLUSIONS}

As the initial data we use the results of empirical observations made on the watersheds in the region of the Small Carpathians, carried out by co-workers of the Institute of Hydrology of the Slovak Academy of Sciences [2]. Figure 1 lists the time (daily) series for the concentrations of nitrates in the Svidnik: Ondrava watershed (1.11.19830.10.1993).

The process is analyzed on the time intervals which are more than the correlation scale, i.e., as one could wait for here, a intermittency has a multi-fractal nature. Using the PC complex "Geomath" (c.f.[15]) we have performed the numerical calculations of the fractal spectrum. Our numerical estimates have shown that the fractals dimensions are lying in the interval [4.2-5.8]. These data are satisfactory agreed with the preliminary estimates within the simple standard multifractal definition modelling. Therefore, our analysis confirms the universal conclusion regarding availability of the multifractal features for the watershed pollutants daily runoff series for the Danube river [22]. 


\section{REFERENCES}

1. Svinarenko A.A., Khetselius O.Yu., Mansarliysky V.F., Romanenko S.I. Analysis of the fractal structures in turbulent processes. Ukr. gidrometeorol. ̌̌ - Ulrainian Hydrometeorology Journal, 2014, no. 15, pp. 74-78.

2. Khetselius O.Yu., Svinarenko A.A. Analysis of the fractal structures in wave processes. Visn. Odes. derž. ekol. univ.- Bulletin of Odessa state environmental university, 2013, vol. 16, pp. 222-226.

3. Abarbanel H.D.I., Brown R., Sidorowich J.J., Tsimring L.Sh. The Mandelbrot B. Fractal geometry of nature. Moscow: Mir, 2002.

4. Schertzer D., Lovejoy S. Fractals: Physical Origin and Properites. N.-Y.: Plenum Press, 1990, pp. 71-92. (Ed.: Peitronero L.)

5. Zaslavsky G.M. Stochasticity of dynamical systems. Moscow: Nauka, 1998.

6. Zosimov V.V., Lyamshev L.M. Fractals in wave processes. Phys.Uspekhi, 1995, vol.165, pp. 361-402.

7. Grassberger P., Procaccia I. Measuring the strangeness of strange attractors. Physica D., 1983, vol. 9, pp. 189-208.

8. Kaplan J.L., Yorke J.A. Chaotic behavior of multidimensional difference equations. Functional differential equations and approximations of fixed points. Lecture Notes in Mathematics. Berlin: Springer, 1979, no. 730, pp. 204-227. (Eds: H.-O. Peitgen, H.-O. Walter)

9. Packard N.H., Crutchfield J.P., Farmer J.D., Shaw R.S. Geometry from a time series. Phys. Rev. Lett, 1980, vol. 45, pp. 712-716.

10. Schreiber T. Interdisciplinary application of nonlinear time series methods. Phys. Rep., 1999, vol. 308, pp. 1-64.

11. Daubechies I. Ten Lectures on Wavelets. Philadelphia: SIAM, 1992.

12. Morlet J., Arens G., Fourgeau E., Giard D. Wave propagation and sampling theory. Geophysics, 1982, vol.47, pp. 203-236.

13. Nason G., von Sachs R., Kroisand G. Wavelet processes and adaptive estimation of the evolutionary wavelet spectrum. J.Royal Stat.Soc., 2000, vol. B62, pp. 271-292.

14. Glushkov A.V., Khokhlov V.N., Svinarenko A.A., Bunyakova Yu.Ya., Prepelitsa G.P. Wavelet analysis and sensing the total ozone content in the earth atmosphere: Mycros technology “Geomath". Sensor Electr. and Microsys.Techn., 2005, vol.2(3), pp. 51-60.
15. Glushkov A.V., Khokhlov V.N., Tsenenko I.A. Atmospheric teleconnection patterns: wavelet analysis. Nonlin. Proc.in Geophys., 2004, vol. 11, no. 3, pp. 285-293.

16. Glushkov A.V., Loboda N.S., Khokhlov V.N., Lovett L. Using non-decimated wavelet decomposition to analyse time variations of North Atlantic Oscillation, eddy kinetic energy, and Ukrainian precipitation. Journal of Hydrology. Elsevier, 2006, vol. 322, no. 1-4, pp. 14-24.

17. Sivakumar B. Chaos theory in geophysics: past, present and future. Chaos, Solitons \& Fractals, 2004, vol. 19, pp. 441-462.

18. Svoboda A., Pekarova P., Miklanek P. Flood hydrology of Danube between Devin and Nagymaros in Slovakia.- Nat. Rep.2000, UNESKO.-Project 4.1. Intern.Water Systems. 2000. 96 p.

19. Pekarova P., Miklanek P., Konicek A., Pekar J. Water quality in experimental basins. -Nat. Rep.1999 of the UNESKO.-Project 1.1. Intern.Water Systems., 1999. 98 p.

20. Balan A.K.,Systems Approach in hydrology: Extremal Hydrological Events and Effect of Changes in Hydrospheres State. Proc. Intern. Conf. "Ecology of Siberia, the Far East and the Arctic". SD RAN, 2001, p. 133.

21. Glushkov A.V., Balan A.K., Multifractal approach for modeling flow and short-term hydrological forecasts (for example, r. Danube). Meteorology, Climatology and Hydrology, 2004, no. 48 , pp. 392-396.

22. Balan A.K. Method multifactorial system modeling in problems of calculation extremal hydrological phenomena. Meteorology, Climatology and Hydrology, 2002, no. 45, pp. 147-152.

23. Glushkov A.V. Khokhlov V.N., Serbov N.G., Balan A.K., Bunyakova Y.Y., Balanyuk E.P. Low-dimensional chaos in the time series of concentrations of pollutants in the atmosphere and hydrosphere. Visn. Odes. derž. ekol. univ.- Bulletin of Odessa state environmental university, 2007, no. 4, pp. 337-348.

24. Glushkov A.V., Khetselius O.Yu., Serbov N.G., Bunyakova Yu.Ya., Balan A.K., Buyadzhi V.V Modelling and forecasting the hydroecological systems pollution dynamics by using a chaos theory methods: I. Advanced data on pollution of the Small Carpathians river's watersheds. Visn. Odes. derž. ekol. univ.-Bulletin of Odessa state environmental university, 2015, no.19, pp.131-136.

\title{
ВЭЙВЛЕТ И МУЛЬТИФРАКТАЛЬНЫЙ АНАЛИЗ НЕЛИНЕЙНЫХ СТРУТУР В ХАОТИЧЕСКИХ ПРОЦЕССАХ ДЛЯ ГИДРОЭКОЛОГИЧЕСКИХ СИСТЕМ
}

Н.Г. Сербов, к.геогр.н.,

А.А.Свинаренко, д-р ф.-м. н., проф.,

О.Ю. Хецелиус, д-р ф.-м. н., проф., О.Н. Грушевский, к.геогр.н.

\author{
Одесский государственный экологический университет, \\ ул. Львовская,15 ,65016, Одесса, Украина, svinarenkoaa@gmail.com
}

Данная работа продолжает наши исследования фрактальных структур в хаотических и турбулентных процессах и связана с большой актуальностью и важностью экспериментального и теоретического изучения нелинейных хаотических динамических систем с целью обнаружения фрактальных структур и свойств и элементов динамического хаоса. На основе вейвлет-анализа и мультифракталь- 
ного формализма осуществляется анализ фрактальных структур в хаотических процессов (временные ряды концентраций нитратов для водораздела Svidník-Ondrava Малых Карпат в Восточной Словакии) и вычислено соответствующий спектр фрактальных размерностей. Выполнен численное моделирование и проведено сравнение теоретических данных с ранее полученными оценками на основе других алгоритмов фрактального анализа.

Ключевые слова: гидрологические системы, фрактальные структуры, хаотические процессы, временные ряды концентраций нитратов

\title{
ВЕЙВЛЕТ І МУЛЬТИФРАКТАЛЬНИЙ АНАЛІЗ НЕЛІНІЙНИХ СТРУКТУР У ХАОТИЧНИХ ПРОЦЕСАХ ДЛЯ ГІДРОЕКОЛОГІЧНИХ СИСТЕМ
}

\author{
М.Г. Сербов, к.геогр.н., \\ А.А,Свинаренко, д-р ф.-м. н., проф., \\ О.Ю. Хецеліус, д-р ф.-м. н., проф., \\ О.М. Грушевський, к.геогр.н.
}

Одеський державний екологічний університет,

вул. Львівська, 15, 65016 Одеса, Україна, svinarenkoaa@gmail.com

Представлена робота продовжує наші дослідження фрактальних структур в хаотичних і турбулентних процесах і пов'язана з великою актуальністю і важливістю експериментального і теоретичного вивчення нелінійних хаотичних динамічних систем з метою виявлення фрактальних структур і властивостей та елементів динамічного хаосу. На основі вейвлет-аналізу та мультифрактального формалізму здійснюється аналіз фрактальних структур в хаотичних процесах (часові ряди концентрацій нітратів для вододілу Svidník-Ondrava Малих Карпат у Східній Словаччині) і обчислено відповідний спектр фрактальних розмірностей. Виконано чисельне моделювання та проведено порівняння теоретичних даних з раніше отриманими оцінками на основі інших алгоритмів фрактального аналізу.

Ключові слова: гідрологічні системи, фрактальні структури, хаотичні процеси часові ряди концентрацій нітратів

Дата первого представления.:03.09.2015 Дата поступления окончательной версии: $\mathbf{2 0 . 1 0 . 2 0 1 5}$ 